DOI 10.22363/2618-897X-2019-16-4-562-579

Research Article

\title{
A Forgotten Translingual Pioneer: Elizaveta Kul'man and her Self-Translated Poetry
}

\author{
Adrian Wanner \\ Pennsylvania State University \\ State College, PA 16801, USA
}

\begin{abstract}
Elizaveta Borisovna Kul'man (1808-1825) is a unique figure in the history of Russian literature, or more precisely, the history of Russian, German, and Italian literature. A child prodigy with formidable linguistic gifts, Kul'man stands out both with her polyglot prowess and outsized literary productivity. At the time of her premature death at age seventeen, Kul'man left behind a vast unpublished oeuvre in multiple languages. The edition of her works published by the Imperial Russian Academy in 1833 contains a trilingual compendium of hundreds of parallel poems written in Russian, German, and Italian. The writing of poetic texts in three languages simultaneously makes Kul'man an early practitioner of what has been called "synchronous self-translation". Not only are the poems linked horizontally as mutual translations of each other, they also pose as translations of a fictitious Greek source. Kul'man thus combines translation, self-translation, and pseudo-translation into a unified whole. This article discusses the genesis of Kul'man's translingualism and explores her trilingual poetics in more detail by following the metamorphosis of one particular poem through its incarnations in Russian, German and Italian. It argues that Kul'man's translingual creativity anticipates more recent developments in twentieth and twenty-first-century poetry produced by globally dispersed Russians.
\end{abstract}

Key words: translingual literature, self-translated poetry, Elizaveta Kul'man

\section{Introduction}

Self-translation has only relatively recently developed into a serious topic of scholarly inquiry. In 1998, Rainier Grutman complained that translation specialists "have paid little attention to the phenomenon, perhaps because they thought it to be more akin to bilingualism than to translation proper" [1]. However, by 2012 Simona Anselmi noted that self-translation had become "a newly established and rapidly growing subfield within translation studies" [2]. An expanding bibliography of academic research on selftranslation, curated by Eva Gentes at Heinrich-Heine University in Düsseldorf, contains over 1,000 entries. In spite of the ever growing volume of research devoted to selftranslation, many issues remain unresolved. One difficulty in coming to terms with this

(C) Adrian Wanner, 2019

This work is licensed under a Creative Commons Attribution 4.0 International License 
phenomenon is the challenge it presents to received notions of translation theory and textual authority. As Jan Hokenson and Marcella Munson have pointed out, selftranslation "escapes the binary categories of text theory and diverges radically from literary norms: here the translator is the author, the translation is an original, the foreign is the domestic, and vice versa" [3].

\section{Discussion}

In collapsing the roles of author and translator, self-translations tend to acquire in the eyes of the reading public a more authoritative status, given that the writer-translator, compared to an extraneous translator, is supposed to be closer to the original text. At the same time, somewhat paradoxically, it is assumed that the author-translator, as the intellectual owner of the text, "can allow himself bold shifts from the source text which, had it been done by another translator, probably would not have passed as an adequate translation" [4]. Not every bilingual or multilingual author is also a self-translator. In his seminal monograph on literary translingualism, Steven Kellman distinguishes between "monolingual translinguals", i.e., authors who write exclusively in an acquired language, and "ambilinguals" who write in two or more languages [5]. "Ambilingualism" seems to be a necessary, but by no means a sufficient condition for self-translation. It should also be noted that the term "self-translation" is in itself ambiguous, depending on whether we see the "self" as the subject or the object of the translational process. If seen as the subject, the self is the agent of textual production. If the self is perceived as the object, self-translation literally involves a "translation of the self". Seen from that angle, any literary writing in a non-native language could be considered a self-translation of sorts, as has been argued by Mary Besemeres [6]. Self-translation, then, is a worthy object of study not only because of the challenges it poses to established notions of translation theory, but also because of the unique questions about bilingual and bicultural identity that it raises.

For a variety of historical, geographical and political reasons, Russia has provided a particularly fertile environment for multilingual writing and self-translation. As an entity uneasily hovering between empire and nation state, the country has given raise both to ideologies of translatability und untranslatability. As Brian Baer has pointed out, the notion of translation lies at the core of Russia's self-definition as a multilingual and multiethnic empire, in which "imperial realities produced an enormous number of bilinguals and a culture marked by hybridity" [7]. The adaptation of French by the Russian aristocracy as a result of cultural self-colonization in the eighteenth century contributed to a widespread practice of bilingualism and linguistic code-switching among the Russian elites.

Even within this context of societal multilingualism, Elizaveta Borisovna Kul'man (1808-1825) presents an extreme case. A child prodigy with phenomenal linguistic gifts, Kul'man stands out both for her polyglot prowess and outsized literary productivity. At the time of her premature death at age seventeen, Kul'man left behind an enormous unpublished oeuvre in multiple languages. Thanks to the efforts of Kul'man's tutor Karl Friedrich von Großheinrich (1783-1860), the Imperial Russian Academy brought out several posthumous editions of her works in the 1830 s and 40 s, including a trilingual 
collection of her Russian, German, and Italian poetry and translations from Anacreon. Starting in the 1840s, Kul'man's collected works in German underwent multiple editions in Germany, while her Italian poetry appeared in Milan. The composer Robert Schumann, who set several of her poems to music, was so taken with Kul'man that he kept a copy of her portrait in his study (see Schumann's "Mädchenlieder" for two soprano voices and piano, op. 103, and "Sieben Lieder von Elisabeth Kulmann" for one voice and piano, op. 104. Both works were composed in 1851).

Despite the posthumous fame that she enjoyed during the second half of the nineteenth century, Kul'man is nowadays a more or less forgotten poet. Nearly everything we know about her is mediated through her tutor, mentor, editor and biographer Großheinrich, who published an extensive biographical sketch of his pupil as a foreword to her "German collected works" [8], and, in Russian translation, in the popular journal Biblioteka dlia chteniia in 1849 [9]. All other accounts of Kul'man's life derive from Großheinrich's testimony, including Aleksandr Nikitenko's biography appended to the Russian Academy edition [10]. As Hilde Hoogenboom has shown, Großheinrich and Nikitenko created two competing biographical narratives. While the former emphasized Kul'man's prodigious intellect and classicist leanings, the latter highlighted her status as a tragic romantic figure cut down by a cruel fate [11].

Großheinrich was certainly not a disinterested biographer. As Kul'man's “discoverer”, educator, mentor, and promoter, his biography is in part calculated to showcase his own crucial role in the development of a person he considered a poetic and linguistic genius. Writing about himself in the third person, Großheinrich projects a persona akin to the tutor of Rousseau's Emile. Since it is the only existing source for Kul'man's life, it is impossible to independently verify the factual accuracy of Großheinrich's account. (It has even been suggested that Großheinrich himself wrote some of the poems attributed to Kul'man. The extant manuscripts of Kul'man's works are all copies in Großheinrich's handwriting, which seems to imitate Kul'man's. See on this Olga Lossewa, "Neues über Elisabeth Kulmann", in Schumann und seine Dichter, ed. Matthias Wendt (Mainz: Schott, 1993, 77-86). My working assumption is that the poems quoted in this article were indeed written by Kul'man, although Großheinrich may have edited them to some extent). With this proviso in mind, his testimony nevertheless deserves attention for the information that it provides about the circumstances of Kul'man's upbringing, the development of her multilingualism, and the origins of her poetry.

Kul'man did not come from a privileged background. Her father, a descendant of seventeenth-century Alsatian immigrants to Russia, was a mid-level army officer and war veteran who had retired from military duty to become a civil servant in St. Petersburg. He died shortly after her birth. Kul'man was raised by her Russian-German mother in a modest hut on Vasiliev Island dependent on the largesse of a distant relative who paid the rent for their lodging. According to Großheinrich's account, signs of an unusual linguistic talent became noticeable very early in Kul'man's life. Her bilingual mother "strove tirelessly to teach her the Russian, and later the German language, as purely as possible". (Großheinrich, "Vorrede", 6. Subsequent page reference to this biography will be given directly in-text. All English translations are my own). Großheinrich, a former friend of Kul'man's father, entered the girl's life when she was five years old. A lawyer by training, he had come to Russia from Germany a few years earlier to serve as a tutor for the children 
of a Russian aristocrat. In view of young Elizaveta's apparent talent, Großheinrich volunteered to teach the child pro bono in his spare time, which he continued to do for the remainder of Kul'man's short life. Großheinrich was himself a formidable polyglot. Having grown up as a German-French bilingual, he also knew Latin and classical Greek as well as English, Spanish, Portuguese, and modern Greek [12]. Over the years that followed, he taught Kul'man all of these languages.

Großheinrich's method of instruction could be described as grammar-translation on steroids. With every new language, he first provided his pupil with a hand-written grammar that listed all the regular morphological endings. At the same time Elizaveta received a book in the new language with a familiar content. She was given the task of reading the foreign book on her own and memorizing all the new vocabulary. Großheinrich reports that with this method, Kul'man was able to become fluent in a new living language within three months (with Latin and Greek it took a few months longer). As soon as she had reached the appropriate level, Elizaveta began to translate from the newly learned language into the languages she already knew, and vice versa. Großheinrich also introduced his pupil to poetry, focusing on a canon of antique and eighteenth-century classicist texts.

By age thirteen, Kul'man had made a prose translation of Anacreon into five languages, and a metric one into her three "favorite languages" Russian, German, and Italian. For the rest of her life, Kul'man continued to translate Anacreon into multiple idioms. The manuscript division of the Russian National Library in St. Petersburg contains, in Großheinrich's handwritten copy, Kul'man's translations of Anacreon's odes into Russian, German, French, Italian, English, Spanish, Portuguese, and Modern Greek [13]. Around 1822/23, Großheinrich sent a selection of Kul'man's Russian and German translations of Anacreon to the Empress Elizaveta Alekseevna, who rewarded the young poet with a diamond necklace. Probably when she became aware of Kul'man's precarious material circumstances, the Empress also granted her a modest annual stipend of 200 rubles.

Knowing eleven languages still did not leave Kul'man satisfied. It only wetted her appetite for more, but her plans for further language learning were cut short by her deteriorating health. In 1824 she had caught cold while attending her brother's wedding. As a consequence of the catastrophic flood of St. Petersburg in November of that year the cold turned into consumption. Kul'man's life could probably have been saved with a cure in a milder climate. However, given her poverty, travelling abroad was out of the question. After a protracted illness, Kul'man died on November 19, 1825, at age seventeen.

At the moment of Kul'man's untimely death, none of her literary works had yet appeared in print. Her oeuvre was of truly enormous proportions. It consisted of a trilingual body of verse translations from Anacreon as well as hundreds of original poems in a pseudo-classical style, all of them in a Russian, German, and Italian version, many more poems written only in German, as well as several fairy tales in Russian and German verse. While few people had ever heard of Kul'man at the moment of her death in 1825, she did become better known in the following decades, especially after the appearance of Nikitenko's and Großheinrich's biographies made the story of her life more widely known. In general, the narrative of a young genius who suffered a life of material deprivation with stoic equanimity and was cut down prematurely by a tragic fate had a greater appeal to the Russian public than Kul'man's actual poetry. Opinions about the quality of her literary work were mixed. Vissarion Belinskii, in his 1841 review of Kul'man's collected works 
published by the Russian Academy, called her a "wondrous and beautiful phenomenon of life", but "no poet whatsoever" [14]. The Decembrist poet and friend of Pushkin Vil'gel'm Kiukhel'beker had a more positive opinion, even though he, too, valued Kul'man's persona higher than her poetry. In a diary entry from January 28, 1835, he wrote that "[Kul'man's] verses are better than all the women's poetry (damskie stikhi) that I had the opportunity to read in Russian, but she herself is even better than her poetry". He regrets that he never met Kul'man in person because he "would no doubt have fallen in love with her" [15]. A day later Kiukhel'beker composed a lengthy ode, in which he presented an exalted vision of Kul'man as an unearthly being appearing among the giants of world literature.

Kul'man fared somewhat better among German critics. None other than Goethe, if we are to believe Großheinrich, expressed a flattering opinion about her poetic gifts. In his biography, Großheinrich reports that, using an acquaintance from his university days as an intermediary, he sent a selection of thirty German, six Italian, and four French poems by the thirteen-year old Kul'man to Goethe in Weimar. The acquaintance wrote back that Goethe was very intrigued by these poems and commissioned him to "tell the young poet in my name, in Goethe's name, that I prophesy for her in the future an honorable rank in literature, she may write in any of the languages known to her".

Overall, Kul'man did acquire a somewhat greater notoriety in Germany than in her country of birth. In part, this may simply be attributable to the larger dimensions of her German oeuvre - more than six hundred of her poems exist only in German. Großheinrich arranged these poems in two "Gemäldesammlungen" ("Collection of Paintings"), each divided into twenty "Säle" ("Galleries"). The first Gemäldesammlung contains 342 poems, and the second 268 (See Sämmtliche Werke, 135-271 and 423-512). Moreover, the German poems differ from the trilingual pseudo-classical Russian-German-Italian corpus by focusing on more modern and personal themes. Some of them address Kulman's poverty, her dreams of poetic fame, and, heartbreakingly, the defeat of her ambitions by her illness and impending death. However, even though her collected works in German went through eight editions in the course of the nineteenth century, Kul'man is now as much a forgotten figure in the German-speaking world as she is in her Russian homeland. Only very recently has she begun to attract the interest of feminist scholars who are looking at her work through the lens of gender studies [16]. A rather curious subgenre of Kul'man criticism has emerged among musicologists and Schumann-biographers. The consensus in that field, at least until recently, was to dismiss her poetry as second- or third-rate, and to explain Schumann's infatuation with Kul'man as, at best, naïve and misguided, or, at worst, a sign of the composer's impending mental illness [17].

In Russia, Kul'man's poetry also elicited negative reactions. Increasingly, her shortcomings as a poet were blamed on Großheinrich, whose role in her biography changed from hero to villain. According to this new narrative, Kul'man's pedantic German tutor forced her to write in an arid, pseudo-classicist style rather than letting her talent develop freely and naturally. Some of the animosity against Kul'man's tutor probably had its origin in wounded national pride: Großheinrich was resented for turning someone into a "German" who would or should have been rightfully a Russian poet. A biography of Kul'man published in 1886 presents her tutor as a foreigner who was completely ignorant of and indifferent to Russian culture. The author argues that "Russia was alien to 
[Großheinrich]; his sympathy belonged to Germany, and the only thing that kept him here was the possibility of good earnings. He knew many foreign languages and literatures, but totally ignored Russian literature and language. Only later did he begin to study it under the direction of his pupil" [18]. This account seems questionable in several respects. First of all, from his biography one does not gain the impression that Großheinrich was particularly well remunerated. Second, and more importantly, while it is likely that he arrived in St. Petersburg with little knowledge of Russian, it is highly unlikely that, as a person of considerable linguistic curiosity and ability, he would not have striven to learn the language of the country where he happened to be living. In fact, Großheinrich's correspondence shows that, at least by the 1830s, he was able to express himself in Russian with native-like ease.

Nevertheless, it is true that Großheinrich initially instructed Kul'man to write her poems in German before translating them into Russian and Italian. The reason, as he explains in his biography, was purely pragmatic: his own knowledge of Russian was insufficient for giving his pupil feedback about poetic diction, and with Kul'man knowing both languages equally well, he felt that it made no difference whether she wrote in Russian or German. It is interesting to note, however, that he later changed his opinion on this account. When Kul'man had become more mature, he advised her to write her poems first in Russian before translating them into other languages. This is not because Großheinrich's own Russian had significantly improved-he conceded that he would still not dare to make technical judgments about Russian verse. Rather, he was of the opinion that Kul'man, even though she had the ambition to become a significant poet in three languages, nevertheless "belonged most of all to her [Russian] fatherland". As he elaborated: "However well you know these two languages [i.e., German and Italian], I am sure that you think in Russian, i.e., that the first expression in which you dress your poetic thought is Russian. You will do best, then, to write down every poem in the language in which you thought it".

As we can see, in spite of his own multilingualism, Großheinrich subscribed to the Herderian notion of a tight confluence between native language and national identity, which, in Kul'man's case, he determined to be Russian. The fact that she had two mother tongues (quite literally-after all, her mother was a Russian-German bilingual) did not deter Großheinrich from assigning Kul'man a clear national identity based on her "fatherland". This unequivocal determination based on patriarchal notions of national belonging is problematic, to say the least, but it seems to invalidate the accusations leveled against Großheinrich by Russian nationalists. Rather than trying to turn his pupil into a German, he tried to convince her of her own Russianness.

Another reproach against Großheinrich is perhaps more pertinent. The choice of authors he presented to Kul'man as role models for poetic writing was decidedly oldfashioned and outdated by the standards of his time. As far as German poetry was concerned, Großheinrich seems to have valued the likes of Gessner and Gleim higher than Goethe and Schiller as pedagogical tools (even though, ironically, he did seek Goethe's verdict about the merits of Kul'man's poetry). Similarly glaring lacunae also exist in Kul'man's exposure to English literature - apparently she was ignorant of Shakespeare, or of contemporary Romantic poetry. The same picture emerges with regard to Russian literature. Given Großheinrich's relative ignorance in that domain, Kul'man's 
education in Russian letters was mainly entrusted to the priest P. S. Abramov, who also taught her Church Slavonic. In a 1832 letter to the president of the Russian Academy A. S. Shishkov, Großheinrich writes that Kul'man was familiar with "Lomonosov, Kheraskov, Ozerov, Derzhavin" as well as Shishkov's own poetic prose translation of Gerusalemme liberate [19]. Focusing on eighteenth-century figures rather than the contemporary literary scene may have been a tactical move to gain the sympathy of the notorious "archaizer" Shishkov. Nevertheless, one cannot help wondering whether Kul'man was aware of Pushkin (who was Shishkov's antagonist and nemesis). There is no evidence that she read any of Pushkin's works. The first four chapters of Pushkin's Eugene Onegin appeared in 1823-25 while Kul'man was still alive, but there is no indication that she read them. Possibly, this ignorance was a consequence of her low socio-economic status, given that the "thick journals" publishing Pushkin's work would have been unaffordable to someone living in poverty [20].

While one may regret Großheinrich's archaic tastes in literature and his failure to expose his pupil to more contemporary writings, there can be no doubt that Kul'man enthusiastically embraced the pseudo-classicist style in which her teacher encouraged her to write. Whether she would have become a better poet without the shackles allegedly imposed on her by her German tutor must remain an open question. In any event, Großheinrich deserves credit for recognizing and nurturing Kul'man's linguistic talent. While opinions about the literary merit of Kul'man's poetry vary considerably, there can be no doubt about her extraordinary polyglot prowess. In that respect it is interesting to note that Goethe, if indeed his verdict is authentic, stressed precisely the multilingual aspect of Kul'man's talent, encouraging her to write in "any of the languages known to her". Kul'man's polyglot poetics and self-translational practice has remained an unexplored angle of her work, even though it is this feature, more than any other, that makes her a unique phenomenon.

The fact that Kul'man resorted to translation as a privileged form of self-expression is not unusual for a Russian woman of her time. As Wendy Rosslyn has shown in her study of Russian female translators in the eighteenth and early nineteenth centuries, women used translation as a preferred entryway to the world of letters, given that " $[\mathrm{t}]$ he task of entering Russian literary life was easier for woman translators than for women poets. Translation was considered less prestigious than original writing and therefore less presumptuous, and it minimized the grounds for accusations of vanity and self-display" [21]. This has to do with the fact, as Sherry Simon has noted, that "[t]translators and women have historically been the weaker figures in their respective hierarchies: translator are handmaidens to authors, women inferior to men" [22]. However, Kul'man differs in two respects from the translators discussed in Rosslyn's study: unlike them, she did not hail from the upper echelons of society, and she blurred the distinction between translation and original writing more radically. While she did engage in bona fide translation work, the majority of her oeuvre consists of pseudo-translations, i.e., of texts that, while presented as translations, are really original creations [23]. Furthermore, by self-translating these texts into other languages, Kul'man undercuts the notion of translation as a subservient genre. In translating herself rather than another person, she abandons the usual auxiliary status of the translator as a handmaiden of the original poet and emerges as the author of multiple "parallel originals". 
What is remarkable about Kul'man is not only her ability to write poetry in multiple languages, but her creation of a vast corpus of linked texts in three languages simultaneously. The edition of Kul'man's poetry published by the Russian Academy contains over a thousand pages. Most of this space is taken up by her "Piiticheskie opyty"/"Poetische Versuche"/"Saggi poetici", a vast trilingual compendium in three parts. Part One contains the translations of twenty-five of Anacreon's odes into Russian and German and a cycle called "Wreath", a series of Greek myths in Russian, German, and Italian verse relating to the metamorphosis of various people into flowers. Part Two, "The Poems of Corinna or a Monument to Eliza" is inspired by the legend of Pindar's defeat by Corinna during the Olympic poetry competitions. Großheinrich suggested to Kul'man that she create a body of poetry in Corinna's name in the same way as McPherson had invented Ossian's poetry. Part Three, finally, entitled "Monument to Berenice" is dedicated to the mother of Ptolemy I and contains poems written in the name of multiple Greek poets of the Hellenistic period.

Kul'man's identification with Corinna deserves particular attention. The German scholar Andrea Geffers has argued that Kul'man, while seemingly accepting the norms of feminine literary production, symbolically criticized the limitations imposed on women's creativity. As Geffers shows, Kul'man's quest for fame, expressed in her impersonation of a female poet who defeated her male competitors, transcends traditional norms of submissive female behavior. By the same token, one could argue that Kul'man's extensive self-translations transcend the subordinate, and therefore feminized, status assigned to translators. The Russian, German, and Italian versions of her poems are linked horizontally as mutual translations of each other while at the same time posing as translations of a fictitious Greek Urtext (or, in the case of Anacreon, they actually are translations of an existing Greek source). Kul'man's collection thus combines translation, self-translation, and pseudo-translation into a unified whole. Given this multiple translational mirror effect, it becomes difficult to determine what, if anything, should be considered the "original".

As has been mentioned before, Großheinrich encouraged Kul'man to write her poems in Russian first before translating them into German and Italian. In reality, though, it appears that she worked on the three versions simultaneously. Großheinrich reports in his biography that "the translations into German and Italian kept in general the same pace as the Russian originals, and were always finished at the same time or at most a few days later". This approach makes Kul'man an early practitioner of what has been called "synchronous self-translation". Aurelia Klimkiewicz defines this phenomenon as "the simultaneous process of writing and self-translating, blurring the boundaries between original and self-translated text" [24]. The most prominent example of a synchronous self-translator in the twentieth century is Samuel Beckett. Not only did Kul'man make a similar effort long before Beckett, she also appears to be the only example of a synchronous self-translator who worked not in two, but in three languages.

We will explore Kul'man's trilingual poetics in more detail by following the metamorphosis of one particular poem through its incarnation in Russian, German, and Italian. "To the Moon" is part of the collection "Monuments to Berenice". Like most poems in Kul'man's trilingual corpus, the text is presented as a pseudo-translation of an 
imaginary Greek original. This particular poem is attributed to the Greek poet Philemon. Großheinrich, who considers “To the Moon” as one of Kul'man's masterpieces, reports that it was included in a collection of exemplary Russian poems for public instruction.

\section{К луне}

Светлая дочь и любимица Неба, Трон занимая эфирный чредой С огненным братом, свергающим токи Злата кипящего с горных высот;

Ты проливаешь из полныя чаши Иль из серебряных ясных рогов, Струи прохладны, дающие силу Смертным, усталым от знойного дня.

Взор их везде следит за тобою, Ходишь ли ты по лазурным полям, Где растет под стопами твоими Светлый сонм разноогненных звезд;

Или медлительным шагом проходишь Длинный чертогов облачных ряд. Царь-соловей, твоего не любящий Брата, тебе воспевает хвалы.

Ты с умилением внемлешь напеву; Смотришь порой, коль он весел, сквозь туч; Или скрываешься в темном их недре, Коль выражает печаль он свою.

Ты во всяком виде прелестна; Но прелестней, когда ты стоишь В западе, рядом с вечерней звездою, В блеске младости нежной твоей.

Вы, двум душам великим подобны, Там сияете - радость земных Без тщеславия, в дружном союзе, Обе довольные сами собой.

(Polnoe sobranie, Russian section, 11-12. The spelling has been modernized, except for the word "polnyia", since the modern form "polnei" would disrupt the meter.)

\section{To the Moon}

Bright daughter and favorite of the Sky, Occupying the ethereal throne in turn

With the fiery brother, who hurls down streams

Of seething gold from mountainous heights; 
You pour from a full cup

Or from silvery bright horns

Cool streams that give strength

To mortals tired from the hot day.

Their gaze follows you everywhere,

Whether you walk across azure fields

Where underneath your steps

A bright swarm of stars grows with various fires;

Or you wander with a slow pace

Through a long row of cloudy chambers.

Tsar-nightingale, not loving your brother,

Sings the praise of your glory.

You listen with tenderness to the song;

Once in a while, if he is cheerful, you peer through the clouds;

Or you hide in their dark depths

If he expresses his sadness.

In any form you are enchanting;

But most enchanting when you stand

In the west next to the evening star

In the splendor of your tender youth.

You, resembling two great souls,

Are shining there - a joy to the mortals -

Without vanity, in a friendly union,

Both pleased with themselves.

The German and Italian versions of the poem read as follows:

\section{An den Mond}

Glänzende Tochter und Liebling des Himmels,

Die den Thron des Aethers du teilst

Mit dem feurigen Bruder, der Ströme

Siedenden Goldes den Höhen entgeusst;

Selbst vergeudest aus voller Schale

Oder aus blendendem silbernem Horn

Sanfte Kühlung du, um nach des Tages

Mühen der Sterblichen Kraft zu erneu'n.

Ueberall folgt dir ihr dankendes Auge,

Sei's dass du das lasurne Gefild

Heiter durchwallest, wo farbige Sterne

Tausendweis deinen Spuren entblühn;

Oder mit zögerndem Schritte die Säle

Deines Wolkenpalastes durchirrst,

Horchend dem Liede des Sängers der Nächte,

Der, der Sonne feind, dich nun erhebt. 
Tönt sein Gesang in fröhlichen Weisen

Lächelnd blickst aus Wolken du dann;

Tönet er Gram, so ziehst du dich trauernd

In des Palastes Tiefen zurück.

Schön bist du Mond, in allen Gestalten, Aber am schönsten, wenn freundlich du

Neben dem Abendstern strahlest im Westen,

In der Jugend blendendem Glanz.

Beide gleicht ihr zwei grossen Seelen,

Die Bewundrung, der Trost der Welt:

Frei von Ehrsucht, und frei von Neide,

Glänzen sie, ihres Verdiensts sich bewusst

(German section, 238.

Again, the spelling has been modernized (e.g., "teilst" instead of "theilst"), except for the archaic or dialectal "entgeusst" ("entgießt" in standard German).

\begin{abstract}
Alla Luna
O figlia primogenita del cielo,

Che alterna ascendi sull' etereo trono

Col fratello di fuoco, che torrenti

Lancia di liquid' auro a se d'interno;

Tu dall'aurata coppa o dalle argentee

Corna ritorte spandi dolce lume,

Che ai miseri mortali, dal soverchio

Lavoro esausti, dà ristoro e forza;
\end{abstract}

Te dovunque ti segue il nostro sguardo,

Sia che passeggi negli azzurri campi,

Ove germoglian sotto i passi tuoi

Stelle infinite, di color diverse;

Sia che traversi d'ambulante reggia

Le smaltate di perle aeree stanze,

Allor che l'usignuol, del Sol nemico,

Per celebrarti alza la chiara voce.

Prestando orecchio all' armoniose note,

Miri, s'ei canta lieto, tra le nubi,

O rimani nel seno loro ascosa,

S'egli in mesta armonia suo duolo esprime.

Tu vezzosa mai sempre in ogni aspetto,

$\mathrm{O}$ Luna! ma vieppiù tale ne sembri,

Quando giovin nel lucido ponente

Splendi alla stella vespertina accanto: 
E come due bell' alme generose,

Sostegno e gioia dell' umana vita,

Non rivali splendete in cielo amiche,

Ambo contente della luce vostra.

(Italian section, 144. Given that the German and Italian versions follow the Russian text relatively closely I will refrain from providing a separate

English translation. Differences in wording will be addressed below).

Großheinrich reports that Kul'man nurtured a special predilection for the moon from her earliest childhood. While the moon appears in many of her poems, "K lune" / "An den Mond" / "Alla luna" is the only treatment of this topic in three languages. The poem also stands out within the corpus of Kul'man's poetry for its choice of meter. Rather unusually for Kul'man, it is written in dactylic tetrameters with alternating feminine and masculine endings. Both in the Russian and the German version there are occasional missing syllables. This looseness of form may be intended to evoke the variegated flow of Homer's epic dactyls, but it can result in clumsy lines, such as the rhythmically awkward "Der, der Sonne feind, dich nun erhebt". The Italian version is written in endecasillabi, i.e., lines of eleven syllables (a standard meter in Italian poetry), with consistent feminine endings. With its fluid regularity the Italian verse shows none of the clumsiness of the Russian and German dactyls.

Perhaps the most intriguing cross-linguistic issue, when comparing the Russian, German and Italian version of the poem, concerns the role of gender. The moon is clearly imagined as a feminine persona-hence the choice of the grammatically feminine word "luna" in Russian (as opposed to the masculine "mesiats", which designates the full moon). This feminine moon is in a state of competition with her "brother", the sun, but she entertains friendly relations with the evening star, another feminine presence in the text. The German version undermines this gender constellation, given that "der Mond" and "der Abendstern" are both grammatically masculine and "die Sonne" is feminine. Rather oddly, the German poem is written nevertheless as if the opposite were true, creating a disjunction between semantics and grammatical gender. In the German version, the femininity of the grammatically masculine moon and the masculinity of the grammatically feminine sun are indicated by kinship terms (the moon is called a "daughter" and the sun a "brother"), while the evening star is simply masculine without any attempt to feminize it. This creates a different gender dynamics than in the Russian and Italian version, where the moon and evening star are presented as female friends. In one instance, Kul'man did insert a "gender correction" in the German text. The nightingale serenading the female moon is masculine in Russian ("solovei") and Italian ("usignuol"). The corresponding German noun ("die Nachtigall") would be feminine, but rather than naming the bird, Kul'man replaced it in the German version with the masculine paraphrase "Sänger der Nächte" ("singer of the nights") in order to maintain the scenario of heterosexual courtship.

Given the difficulties of matching semantics and grammar in German, we have to assume that the poem was originally conceived in Russian. Or did the inspiration come from the Italian? Interestingly, the gender constellation of the poem works best in that 
language. Not only are the moon ("luna", using the same word as in Russian) and the evening star ("stella vespertina") grammatically feminine, the sun (not named directly in the poem) is masculine in Italian. This makes the designation "fiery brother" more natural in Italian than in Russian, where the sun is grammatically neuter (in German, as already mentioned, the sun is feminine, which turns its status as "brother" into a grammatical oxymoron). Since the poem is presented as a pseudo-translation from Greek, it may be worth mentioning that the sun and the moon are masculine and feminine in Greek as well, which means that the Italian version comes closest to the gender constellation of the imaginary Greek "original”. Moreover, the sense of female solidarity between the moon and the evening star is expressed most succinctly with the Italian word "amiche" ("[female] friends"). In Russian the plural of the word "friend" cannot be marked for gender. In German, while technically possible ("Freundinnen"), it would sound rather awkward.

While there are no major semantic deviations between the three versions, they do differ in a multitude of details. By comparison, the Italian text has more of a "life of its own", i.e., it contains more elements that exist in that version alone and cannot be found in the other two languages. In Italian the moon is called the "first-born" daughter of the sky, while it is the "favorite" daughter in Russian and German. The sun radiates not from above, but from its inner core (which seems more astronomically sound), while the moon pours out its light from a "golden" cup rather than a "full" cup. The "mortals" in stanza two seem more miserable in the Italian version-they are "exhausted from excessive labor", while they are suffering mainly from the heat in Russian and German. The cloudy chambers of the moon are "coated with pearls" only in Italian. The song of the nightingale is called "harmonious" (twice) in Italian, but not in Russian or German. The moon and evening star are "generous souls", as opposed to "great souls" in Russian and German. In one instance, we can observe a sort of amplification in the passage from Russian to German to Italian: the "swarm" of stars in Russian turns into "thousands" of stars in German, and "infinite" stars in Italian. The final line also differs in the three versions: in Russian the moon and evening star appear smugly "pleased with themselves", in German, rather ponderously, they are "conscious of their own merit", while in Italian they are "pleased with [their] light".

In general, the poem seems more compelling in its Italian incarnation than in Russian or German. This is true for many of the poems in Kul'man's trilingual corpus. To a modern reader, and no doubt even to a reader of her own time, Kul'man's Russian style makes an archaic impression. The numerous Slavonicisms typical of eighteenth-century poetry appear awkward and ponderous in the context of the Pushkin period. Her German, while slightly more modern than her Russian, also feels somewhat outdated. This is no doubt the consequence of a schooling in German literature that focused almost exclusively on eighteenth-century models. By contrast, Kul'man's Italian seems more contemporary and elegant. At first sight, this may appear surprising, given that her Italian role models Dante, Petrarca, Tasso - were even more ancient than the eighteenth-century Russian and German poets that she had been encouraged to emulate. However, we have to remember that Italy reached its poetic pinnacle centuries earlier than Russia and Germany. In that sense, Kul'man's study of classic Italian literature may have provided her with a 
better instrument for poetic creation than the antiquated brand of Russian and German poetry that was imparted to her by her teachers Abramov and Großheinrich.

There is another factor that distinguishes Italian from Russian and German. While Russian and German were Kul'man's mother tongues, Italian was a chosen language. The special affective status that Italian had for her may precisely lie in its foreignness: it was an idiom that her mother did not know, and, unlike French, it was not a language routinely spoken by upper class Russian society. In consequence, Italian offered to Kul'man an alternative identity from her Russian-German roots. Together with all the other languages that she learned, it provided an escape hatch from her impoverished life on the fringes of Russian society and helped to fulfill her frustrated longing for cultural expansion and travel. Similar to Ancient Greece, Italy turned into an idealized locus of Kul'man's imagination and yearnings. While any new language was a source of pleasure and excitement for Kul'man, no other idiom seems to have stimulated her as much as Italian. Großheinrich writes that "as soon as Elisabeth had three or four lessons in Italian, she declared to her teacher that she probably would learn no other language with such assiduousness as Italian, because this latter seemed to her to surpass all others in gracefulness and euphony".

The trilingual edition published by the Russian Academy contains two dedications directed specifically to Kul'man's German and Italian readers. Written only in German and Italian, these poems seem to have been composed shortly before her death. The German dedication addresses the women of Germany with a plea to "remember once in a while / the poor girl from the north, / who, without knowing you / adores you, and in the spring / of her years is dying". The Italian poem, written in an even more emotional tone, begins with a declaration of love:

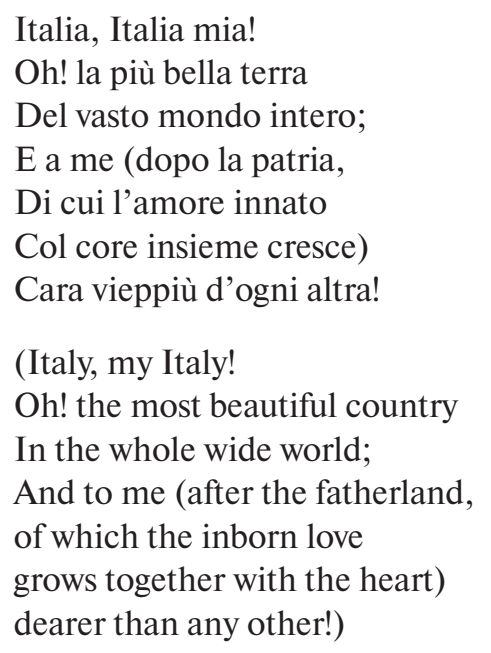

After summarizing the crucial role that Italian poets and the Italian language played in her life, Kul'man ends her poem with the words:

Italia idolatrata,

Ti scrissi queste righe.

Dolce mia vita, addio!

Addio, Italia mia! 
(Idolized Italy,

I wrote these lines for you.

My sweet life, farewell!

Farewell, my Italy!)

It looks almost as if Kul'man had to forcefully remind herself of the love that, as a loyal subject of the Tsar, she owed her Russian fatherland, while her real attachment belonged to a country that was neither her fatherland nor her motherland.

Kul'man's example demonstrates that a strong emotional connection can very well exist to a non-native language, and that this language can become a preferred instrument of poetic expression in spite, or perhaps, because of its foreignness. It is probably no accident that, aesthetically and stylistically, Kul'man's poetic oeuvre is rooted in the eighteenth century rather than the romantic period. As a poet, she was still unencumbered by Herderian notions of "language loyalty" and thus able to create in multiple linguistic spheres simultaneously. By the same token, the massive trilingual edition of her works published by the Imperial Russian Academy in the 1830s speaks to an official tolerance and acceptance of multilingualism that was to vanish with the increasing spread of a patriotic ideal equating the national language with the national soul.

\section{Conclusion}

For the rest of the nineteenth century, in spite of the Russian-French bilingualism of the Russian upper class, poetic self-translation remained a marginal phenomenon. Pushkin did write a few French poems in his youth, but it never would have occurred to him to self-translate his Russian poems into other languages. The only major Russian poets of the nineteenth century who did engage in this activity, although on a rather modest scale, were Vasilii Zhukovskii (1783-1852) and Evgenii Baratynskii (1800-1844). Zhukovskii translated a total of thirteen of his Russian poems as well as a fairy tale into German. Most of his German self-translations were written after his permanent relocation to Germany in 1841, where several of his German works appeared in print during the final years of his life [25]. Baratynskii translated twenty of his poems into French in order to make them accessible to his Parisian friends and acquaintances. Neither Zhukovskii nor Baratynskii preserved the form of the Russian originals in their translations, preferring to create "free" prose versions [26]. Afanasii Fet (1820-1892), another major nineteenthcentury poet, was, like Kul'man, a Russian-German bilingual who would have been perfectly capable to write in either language. Yet the only available example of a selftranslation by Fet is a rather humdrum circumstantial poem written on the occasion of a relative's silver marriage celebration.

The practice of poetic self-translation only returned after a long hiatus, when the monolingual paradigm imposed by romantic ideology had run its course. The spirit of linguistic experimentation inspired by the advent of modernism led, a hundred years after Kul'man, to a renewed exit from the mother tongue, a trend reinforced by the massive uptick in emigration after the Bolshevik revolution. Unlike Kul'man, who never left her native city and became a world-traveler only in her imagination and through her multilingual practice, this new generation of cosmopolitan poets, whether by choice or 
necessity, engaged in actual travel and frequently ended up in permanent dislocation from the native land. In consequence, self-translation became a more common practice again, as we can see from the bilingual poetic oeuvre of Marina Tsvetaeva, Vladimir Nabokov, or Joseph Brodsky, to name only the most prominent examples.

Over the past thirty years, we have witnessed an unprecedented global dispersion of Russian speakers over three continents, leading to the emergence of a new generation of bilingual or multilingual "diasporic" Russians dwelling in the countries of the so-called "Near Abroad" as well as in Israel, Germany, the United States, and elsewhere. The "postmonolingual condition" that is affecting a growing number of today's global population and creative writers has ushered in an era of transnational mobility and linguistic mixing. In an 1979 interview with John Glad, Joseph Brodsky speculated that "in twenty or thirty years there will be people for whom [producing poetry in multiple languages] is completely natural'" [27]. We should not forget that, two hundred years before our time, Elizaveta Kul'man was an early pioneer of this trend.

\section{References}

1. Grutman, R. 1998. "Auto-translation", in Routledge Encyclopedia of Translation Studies, ed. Mona Baker. London: Routledge. P. 17.

2. Anselmi, S. 2012. On Self-Translation: An Exploration in Self-Translators' Teloi and Strategies. Milan: LED. 11.

3. Hokenson, J., and M. Munson. 2007. The Bilingual Text: History and Theory of Literary SelfTranslation. Manchester, Eng.: St. Jerome. P. 161.

4. Perry, M. 1981. "Thematic and Structural Shifts in Autotranslations by Bilingual Hebrew-Yiddish Writers: The Case of Mendele Mokher Sforim”. Poetics Today 2 (4): 181.

5. Kellman, S.G. 2000. The Translingual Imagination. Lincoln: University of Nebraska Press. P. 12.

6. Besemeres, M. 2002. Translating One's Self: Language and Selfhood in Cross-Cultural Autobiography. Oxford: Peter Lang.

7. Baer, B.J. 2016. Translation and the Making of Modern Russian Literature. New York: Bloomsbury Academic. P. 14.

8. Großheinrich, K.F. 1847. "Vorrede", in Sämmtliche Gedichte von Elisabeth Kulmann. Leipzig: Verlag von Otto Wigand. Pp. 3-132.

9. “Elizaveta Kul'man i ee stikhotvoreniia”, Biblioteka dlia chteniia 94 (4): 69-117; 95, no. 5 (1849): 1-34 and no. 6 (1849): 61-96; 96, no. 6 (1849): 83-119.

10. Nikitenko, A. 1839. "Zhizneopisanie devitsy Elizavety Kul'man”, in Polnoe sobranie russkikh, nemetskikh i ital'ianskikh stikhotvorenii Elizavety Kul'man. St. Petersburg: Tipografiia Imperatorskoi Rossiiskoi Akademii.

11. Hoogenboom, H. 2001. "Biographies of Elizaveta Kul'man and Representations of Female Poetic Genius”, in Models of Self, eds. Marianne Liljeström, Arja Rosenholm and Irina Savkina. Helsinki: Kikimora. P. 22.

12. Kulmann, E. 1981. Mond, meiner Seele Liebling. Eine Auswahl ihrer Gedichte, ed. Hansotto Hatzig. Heidelberg: Meichsner \& Schmidt, pp. 23-25.

13. Bruppacher, H. 1991. "Erinnerung an Elisabeth Kulmann: Eine russische Dichterin aus dem frühen 19. Jahrhundert”. Neue Zürcher Zeitung 201: 65.

14. Belinskii, V.G. 1954. Polnoe sobranie sochinenii. T. 4: Stat'i i retsenzii 1840-1841. Moscow: Izdatel'stvo Akademii Nauk SSSR. 570 P.

15. Kiukhel'beker, V. 1967. Izbrannye proizvedeniia v dvukh tomakh, ed. N.V. Koroleva. MoscowLeningrad: Sovetskii pisatel' 1: 640.

16. Geffers, A. 2007. Stimmen im Fluss: Wasserfrau-Entwürfe von Autorinnen. Literarische Beiträge zum Geschlechterdiskurs von 1800-2000. Frankfurt. M.: Peter Lang, 2007), pp. 59-102. 
17. Schumann in Düsseldorf: Werke, Texte, Interpretationen, ed. Bernhard R. Appel. Mainz: Schott, 1993), pp. 119-126. 119-121.

18. Durylin, S. 1937. "Pushkin i Elizaveta Kul'man", 30 dnei 2: 87.

19. Ganzburg, G.I. 1995. “K istorii izdaniia i vospriiatiia sochinenii Elizavety Kul'man”, Russkaia literatura 1: 150 .

20. Leve, E.A. 1915. "Pervaia v Rossii neofilologichka”, Zapiski neo-filologicheskogo obshchestva 8: 218.

21. Rosslyn, W. 2000. Feats of Agreeable Usefulness: Translations by Russian Women 1763-1825. Fichtenwalde: Verlag F.K. Göpfert. P. 169.

22. Simon, S. 1996. Gender in Translation: Cultural Identity and the Politics of Transmission. London: Routledge.

23. Toury, G. 2012. Descriptive Translation Studies - and beyond. Revised edition Amsterdam: John Benjamins Publishing Company, pp. 47-59.

24. Klimkiewicz, A. 2013. "Self-Translation as Broken Narrativity: Towards an Understanding of the Self's Multilingual Dialogue", in Self-Translation: Brokering Originality in Hybrid Culture, ed. Anthony Cordingley. London: Bloomsbury. P. 190.

25. Gerhardt, D. 1970. "Eigene und übersetzte deutsche Gedichte Žukovskijs”, in Gorski Vijenac: A Garland of Essays Offered to Professor E.M. Hill. Cambridge, Eng.: Cambridge University Press, pp. $118-154$.

26. Nikonova, N., and Yu. Tikhomirova. 2018. "The Father of Russian Romanticism's Literary Translingualism: Vasilii Zhukovskii's German Compositions and Self-Translations”, Translation Studies 11 (2): 139-57.

27. Brodskii, I. 2007. Kniga interv'iu, ed. V. Polukhina. 4th ed. Moscow: Zakharov, p. 123.

\section{Article history:}

Received: 27.04.2019

Accepted: 29.07.2019

Moderator: S. Kellman

\section{Conflict of interests: none}

\section{For citation:}

Wanner, A. 2019. "A Forgotten Translingual Pioneer: Elizaveta Kul'man and her Self-Translated Poetry". Polylinguality and Transcultural Practices, 16 (4), 562-579. DOI 10.22363/2618-897X2019-16-4-562-579

\section{Bio Note:}

Adrian Wanner is Liberal Arts Professor of Slavic Languages and Comparative Literature at Pennsylvania State University. He was born and raised in Switzerland and received his Ph.D. in Russian literature from Columbia University in 1992. Wanner is the author of Baudelaire in Russia (1996), Russian Minimalism: From the Prose Poem to the Anti-Story (2003), and Out of Russia: Fictions of a New Translingual Diaspora (2011). In addition he has published six editions of Russian, Romanian, and Ukrainian poetry in his German verse translation. His most recent book, a study of self-translation among Russian poets, is forthcoming in Spring 2020 with Northwestern University Press. E-mail: ajw@psu.edu 


\title{
Забытый пионер транслингвизма: Елизавета Кульман и ее самопереводная поэзия
}

\author{
А. Ваннер \\ Университет Пенсильвании \\ Пенсильвания, 16801, США
}

Елизавета Борисовна Кульман (1808-1825) - уникальная фигура в истории русской литературы, точнее, истории русской, немецкой и итальянской литературы. Вундеркинд с огромными лингвистическими способностями, Кульман отличается как своим мастерством полиглота, так и огромной литературной продуктивностью. Кульман оставила огромное неопубликованное наследие на нескольких языках. Издание ее произведений, опубликованное Императорской Российской Академией в 1833 году, содержит трехъязычный сборник из сотен параллельных стихов, написанных на русском, немецком и итальянском языках. Написание поэтических текстов на трех языках одновременно делает Кульман ранним практиком так называемого синхронного самопереведения. Мало того что стихотворения связаны горизонтально как взаимные переводы, они также представлены как переводы вымышленного греческого источника. Таким образом, Кульман объединяет перевод, самоперевод и псевдоперевод в единое целое. В этой статье обсуждается генезис транслингвизма Кульман и более подробно рассматривается ее трехъязычная поэтика. Автор статьи рассматривает метаморфоз одного конкретного стихотворения через его воплощения на русском, немецком и итальянском языках. Многоязычное творчество Кульман предвосхищает более поздние события в поэзии XX и XXI веков, созданной русскими авторами, разбросанными по всему миру.

Ключевые слова: транслингвальная литература, самопереводная поэзия, Елизавета Кульман

\section{История статьи:}

Дата поступления в редакцию: 27.04.2019

Дата принятия к печати: 29.07.2019

Модератор: С. Келлман

Конфликт интересов: отсутствует

\section{Для цитирования:}

Ваннер А. Забытый пионер транслингвизма: Елизавета Кульман и ее самопереводная поэзия // Полилингвиальность и транскультурные практики. 2019. Т. 16. № 4. С. 562-579. DOI 10.22363/2618-897X-2019-16-4-562-579

\section{Сведения об авторе:}

Адриан Ваннер - профессор гуманитарных наук и сравнительной литературы в Университете штата Пенсильвания. Он родился и вырос в Швейцарии и получил докторскую степень по русской литературе в Колумбийском Университете в 1992 году. Ваннер - автор книги «Бодлер в России» (1996), «Русский минимализм: от прозаической поэмы до антисказки» (2003) и «Из России: выдумки новой многоязычной диаспоры» (2011). ). Кроме того, он опубликовал шесть изданий русской, румынской и украинской поэзии в своем немецком переводе стихов. Его последняя книга, посвященная изучению самостоятельного перевода среди русских поэтов, выходит весной 2020 года в издательстве Northwestern University Press. E-mail: ajw@psu.edu 